PROBLEMS

OF EDUCATION

IN THE $21^{\text {st }}$ CENTURY

Volume 39, 2012

\section{IMPLEMENTING E-LEARNING ENVIRONMENT IN REAL VOCATIONAL SCHOOL}

\author{
Ilche Acevski, Valentina Acevska \\ Vocational School SOTU "Gjorgi Naumov", Bitola, FYR Macedonia \\ E-mail: iacevski74@gmail.com, valle.mk@gmail.com \\ Linda Fahlberg-Stojanovska \\ Faculty of Technical Sciences, Bitola, FYR Macedonia \\ E-mail: Ifahlberg@gmail.com
}

\begin{abstract}
Students in vocational schools in Macedonia are less motivated and both enter and finish with ever decreasing knowledge. Teachers are still keeping to conventional ways of teaching. How to improve this situation? Is it possible that a Moodle eLearning environment will do this? The project, by itself, will lead to easier communication between students and teachers, 24-hour support for the students learning needs, modern e-learning and improvement of the teachers Information and Communication Technology (ICT) competences. With implementation of this educational plan, both teachers and students will increase their use of ICT (e-tests and quizzes, online teaching, preparation of electronic multimedia lectures) and improvement of the group and team work among teachers and students as well. In surveys, teachers and students confirmed that they want to be trained to begin to use the eLearning environment, and underwent training. Also, video tutorials are prepared for that purpose. The results can be seen through observations and interviews in which students are asked if this project started to improve their knowledge skills and whether teachers have started to prepared electronic resources and activities for them.
\end{abstract}

Key words: eLearning, ICT, moodle, teachers, school, students, surveys, vocational.

\title{
Introduction
}

Vocational Education focuses on achieving skills and knowledge necessary for realworld industries. In vocational schools students gain practical experience, develop and improve entrepreneurial and employability skills and many others. But students in vocational secondary schools in Macedonia are less motivated and both enter and finish with ever decreasing knowledge. Most of the teachers still retain conventional ways of teaching.

For many years are discussed about new technologies in teaching and how teachers accept it. "Professionally we are a conservative folk. We are only too willing to keep on, in our old ways. But we are also a profession with a conscience of some sensibility. Most of us want to be up to date in our methods, and young teachers are particularly keen to keep abreast of all the latest educational developments. They are always on the look out for some new thing, and their early career is sometimes marked by a surprising series of quick changes. Changes of point of view and of method during a teacher's career give evidence of vital force. The man is not stagnating. Each change as it occurs is an indication that he is reacting on his own environment, modifying it to meet his own needs and the needs of his pupils, behaving, in fact, as a healthy organism should." (Adams, 1923).

The NMC Horizon Report: 2011 K-12 Edition talks about new technologies and their use in learning, teaching and creative expression within the secondary education. "Those who have the opportunity to learn technology skills are in a better position to obtain and make 
use of technology than those who do not. The perceived value of innovation and creativity is increasing." (Johnson, Adams, Haywood, 2011).

What about the learning styles of students?

Vermunt (1992) talks about various learning styles: a reproduction, an application and a meaning directed learning styles and also an undirected learning style. A reproduction directed learning style is characterized by reproducing study behavior of the students. Students characterized by an application directed learning style prefer to learn within actual, real-world. Students with a meaning directed learning style want to understand study material and try to develop their own view. Students with an undirected learning style have a lot of problems with study materials and they need more time.

The Dunn and Dunn (1999) model identifies visual, auditory and kinesthetic or tactile learners. Visual learners better learn through pictures, charts and other visible material. Auditory learners are usually talkative, they learn through dialogue and prefer discussions and debates. Kinesthetic learners want to touch, move and do things with their own hands. They may stay without concentration if there no external stimulation or movement (Prashnig, 2004). Usually, all three ways are used by any individual, but one is dominant. According to Edgar Dale (1969), a man learns $10 \%$ of what he reads, $20 \%$ of what he hears, $30 \%$ of what he sees, $50 \%$ of what he both hears and sees, $70 \%$ of what he discusses with others, $80 \%$ of what he experiences himself and $90 \%$ of what he teaches to someone else.

In this research, a main theme is how ICT can create new learning environments and changing their role from a teacher-centered to a student-centered environment. Teachers change their role from main source of knowledge and information to that of a collaborator, coach and co-learner. Students would be actively involved in different activities and can choose their own learning style, and also where and when to do that activities. Past few years has proved that efforts for quality education and equal educational opportunities for all, must be supported by reforms in education. "Teachers must have access to adequate training and ongoing professional development and support and be motivated to use new teaching and learning methods and techniques." (UNESCO, 2005).

The main purpose of this research is to improve the success of students and to be able to find their own style of learning, and also, to move teachers away from conventional ways of teaching by using ICT. It can also be said that less and less students are enrolling in vocational schools from year to year. So this research, design and development of eLearning environment should indirectly contribute to the good publicity of the school and increasing the number of students who enroll in the school.

\section{Methodology of Research}

In 2008, the project "Computer for Every Child" began by the Ministry of Education and Science of FYR Macedonia and by 2011 almost every school got computer with internet for each student. Also, at the vocational school where this research was done, almost every student has a computer and internet at home. But how are the computers used? How to engage students with the possibilities of ICT, but in learning activity, not just in recreational? Would the use of a virtual learning environment such as Moodle make the learning more exciting and also make the teaching more interesting? When ICT is integrated correctly, it is able to motivate teachers and students, gives the students real-world skills and help them to learn how to get better learning experiences and be productive members in 21 st century.

As this research includes Moodle, let see what kind of learning environment is it. "Moodle is the perfect platform for experimenting with new and emerging technologies, applications, and tools. Moodle is a Course Management System (CMS) for producing web-based courses. A course that has been built in Moodle encourages learners to engage with the material on many 
PROBLEMS

OF EDUCATION

IN THE $21^{\text {st }}$ CENTURY

Volume 39,2012

10

is a built-in flexibility that allows the learner to approach the material in ways that work for $\mathrm{him} / \mathrm{her}$. Keep in mind that each learner has his/her own style, and the best learning programs accommodate learning styles and preferences. So, whether or not the participants in the course are auditory, visual, or kinesthetic learners, they must be taken into consideration, and the instructional activities as well as assessments should reflect those possibilities. Learners have options, not just with the course content but also in the approach they take to the material and to their peers."'(Rice, Smith Nash, 2010).

The project, by itself, will lead to easier communication between students and teachers, 24-hour support for the students learning needs, modern e-learning and improvement of the teachers IT competences. In 2010/2011 school year, the first virtual learning environment of the school host was created as a subdomain on the web site: http://e-learning.gorginaumov. edu.mk. That was a first step, more like a test or experiment. Electronic materials and some activities were prepared for students in several courses and students were satisfied with the changes. All teachers had possibilities and access in their courses, but there was no initiative from their side. This emerged the question: How to improve this situation?

So in 2011/2012 school year was developed a research plan, followed by creating a new subdomain http://e-uciliste.gorginaumov.edu.mk. This research includes 2 initial phases. The first phase (more like a preparation phase) included one teacher who prepared electronic multimedia lectures, quizzes and other activities for their own students in second quarter from the first half of the school year, after weak first grades in first quarter. These activities were prepared for 2 classes with 63 students in 3th year (subject: Digital Systems), and for 3 classes with 82 students in 4th grade (subject: Process Control), or total 145 students. Some of the prepared lectures, quizzes and other activities can been seen at http://tinyurl.com/8a3cezr.

After a generally successful first phase, the second phase followed where Moodle was organized for all 71 teachers (see on http://tinyurl.com/6ry3qtw) and for all 792 students in the school. In this phase, after organizing Moodle, via surveys, both teachers and students were asked if they want to be trained, and to begin to use the eLearning environment. Both surveys were in native language, for the students (http://tinyurl.com/753rh8p) and for the teachers (http://tinyurl.com/7durqyk), and was created by Form in Google Docs.

The survey for the teachers was answered by 50 teachers. There was 17 questions in survey, but 9 of them were particularly important for this research. For example: " 2 . Does the abundance of resources and relationships which are easily accessible via the Internet increase the challenge for us to review our roles as educators?", "3. Do you think ICT profoundly affect the way we work, collaborate, communicate, and succeed?", "5. Does the use of ICT stimulate innovation, creativity, interest and motivation among students?", "7. Would you use the possibility of making electronic quizzes (tests) that can be used for formative assessment at the end of the lesson or at any time, but also for the final assessment?", "10. Would you like to attend a short training for using ICT with your students in which you learn to create materials in electronic form, make quizzes of varying difficulty, duration and time, create assignments for students different tasks, using video conferencing and so on, which will then be made available 24/7?" Some of the questions in the surveys were provoked by Johnson, L., Adams, S., and Haywood, K., (2011). The survey for the students was answered by 213 students (8-10 of each class, not including the 5 classes from the first phase). There was 17 questions (similar with that of a teachers survey, but prepared for students), and 8 of them was for this research. Some of the questions were: 2 . Does ICT should profoundly affect the way you work, collaborate and interact with teachers? 3. Would it increase your motivation and interest if you are able to work, learn and solve problems at anytime and anywhere, not only at the classes? 5. Do you think that by using electronic (doc, ppt, pdf etc) or multimedia lectures, available $24 / 7$, that this would increase your interest and motivation? 7 . Would you like to try some extra or additional 
classes to hold through video conference if it is provided by the school? 8. Do you think that the use of ICT in ways that are mentioned in the above questions would raise your skills and

achievements as a student?

The importance of this research can be seen by an analysis of grade results of students in the two previous school years. In 2009/2010 school year, from 884 students with 256 in 1st, 218 in 2nd, 206 in 3rd and 204 in 4th year of study, the success at the end of the school year was as follows: 104 students completed with a grade average of 5 (highest), 96 with 4, 245 with 3, 431 with 2 (passing) and 8 with 1 (fail). So the average grade was 2.84. In 2010/2011 school year, from 813 students with 184 in 1st, 247 in 2nd, 210 in 3rd and 172 in 4th year of study, the success rate was: 80 students completed with 5,103 with 4, 218 with 3, 397 with 2 and 15 with 1 . So the average grade was 2.80 . In 2011/2012 school year only 171 students were enrolled in first year of study. From this, it can be seen that both the success and the number of students enrolled in first study year is continuously decreasing. As we said above, research has shown that this improvement can come when students find their own learning style. To do this teachers must provide and use new teaching techniques for students both while in school and via the eLearning platform. This will positively affect more and more students each year as the eLearning platform expands and more and more teachers participate.

\section{Results of Research}

For the first phase, the research took place within the school's classrooms with computers and internet, and also with online students' activities at home, for students of the five already mentioned classes. The grades of the students for the first half of the school year (at the end of December 2011) compared with grades at the end of first quarter (at the end of October 2011) were pretty much satisfying. At following link: http://tinyurl.com/7263upj, grades of all students can be seen as taken from the electronic grade book (names of the students are blurred according to the law on protection of personal data in our country). These results in percentage are shown on figure 1 .

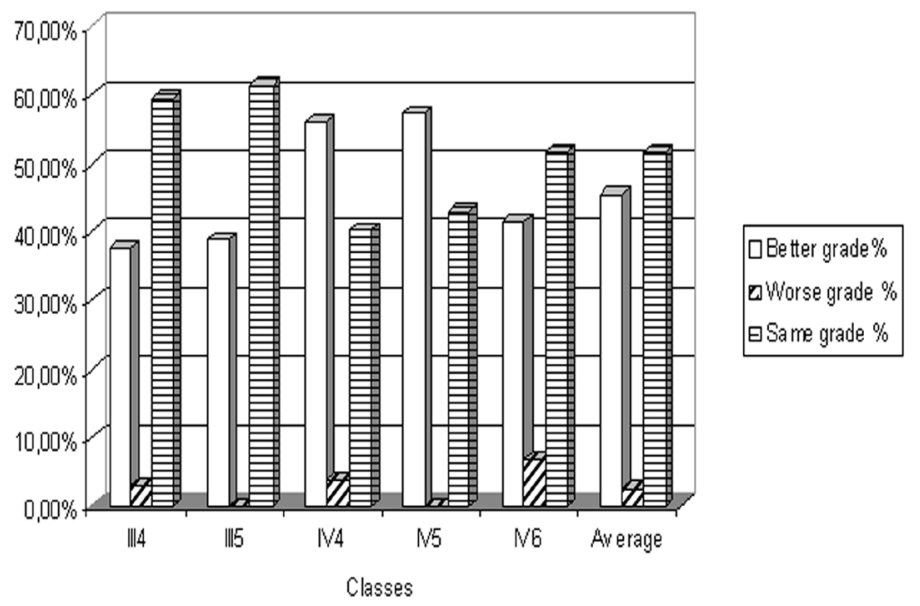

Figure 1: Results of the students' grades in 5 classes for the first phase of research.

In the second phase, after organizing Moodle, in surveys, teachers and students confirmed that they want to be trained, and to begin to use the eLearning environment.

Results shows that about $80 \%$ of surveyed teachers wished to attend the training to use the Moodle platform. This is shown on Figure 2, for every question from the teachers' survey. Original results (in Macedonian) can be seen at http://tinyurl.com/73o6rur. 
PROBLEMS

OF EDUCATION

IN THE $21^{\text {st }}$ CENTURY

Volume 39, 201

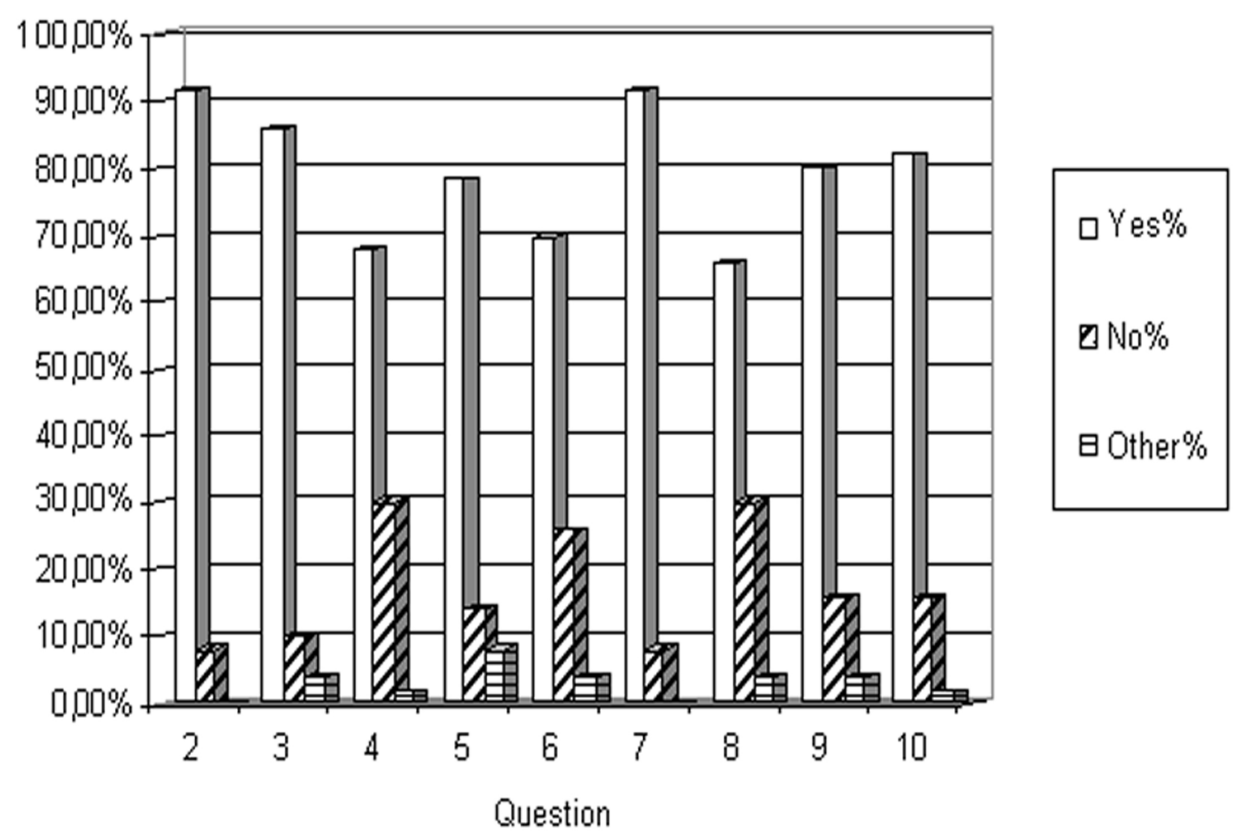

Figure 2: Results from the teachers` survey.

Results shows that about $80 \%$ of surveyed students wished to use the Moodle platform. This is shown for every question on Figure 3. Original results from the students can be seen at http://tinyurl.com/7ldnavj.

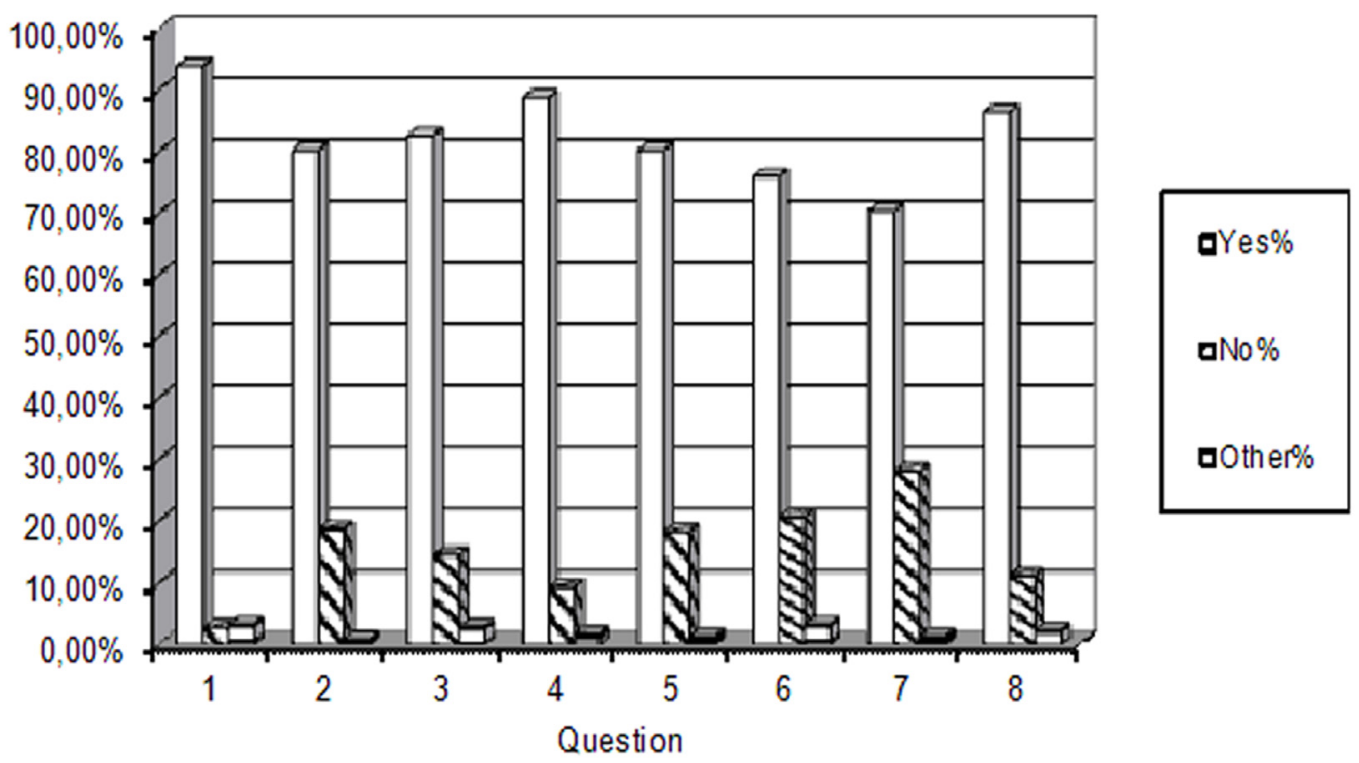

Figure 3: Results from the students` survey.

\section{Discussion}

In the first phase in almost all classes, over $37 \%$ to $57 \%$ of the students have better grades than their first grades, $45.52 \%$ of all students have better results, and $51.72 \%$ have the 
same result (Figure 1). We believe that these results can be improved with greater engagement

After concluding that about $80 \%$ of surveyed teachers wished to attend the training to use the Moodle platform (Figure 2), and that about $80 \%$ of surveyed students wished to use the Moodle platform, training has been organized. Three groups of 20 teachers each, attended training in January 2012. Tutorials were prepared in written and video format. Video tutorials can be seen at http://gorginaumov.edu.mk/?page_id=1684. Also, tutorials in written format can be seen at http://www.issuu.com/ilceacevski/docs/online_uciliste. In these tutorials, also, are electronic multimedia lectures, quizzes and other activities prepared for the first phase of this research, organization of Moodle and so on.

But maybe the most important thing is that this eLearning platform can be used by the students at home and not only in the school. In the student's survey, $93.90 \%$ of students answered that they have computer with internet at home, which is very similar with average across OECD countries, where $94 \%$ of students reported that they had a computer at home. In OECD (2011) might be seen comparison between PISA 2000 and OECD research in 2009. For example, the number of students who confirmed at least one computer at home increased from $72 \%$ in 2000 to $94 \%$ in 2009 . Also, the opportunities for 15 -year-old students to access the Internet have improved dramatically, from $45 \%$ to $89 \%$ between 2000 and 2009. In research from $2009,93 \%$ of students answered that have access to computers connected to the Internet at school. Macedonia may be a leader in this field (in primary and secondary education) with almost $100 \%$ since 2010 , as it was mentioned above. Now the question is how these computers to be used for the right purposes. It is the main goal of this research.

What about teacher training? Yves Punie, Dieter Zinnbauer and Marcelino Cabrera, (2008) in research for European Commission find that "The need for teacher training is widely acknowledged. Teachers, trainers, and other learning facilitators have to be given the knowledge, examples and time to "adopt" ICT in their daily practice. One of the problems is that today's teachers need to learn to teach with digital technologies while many of them have not been taught to do so. This report also find that most of case studies highlight positive impacts of teacher training with digital technologies, such as increasing teacher confidence and competence in the use of IT resources by providing them a good training. Training teachers to use digital technologies could also include the use of ICT for assessment of learning outcomes, although teachers are not the only actors concerned with assessment. Assessment is indeed central to educational practice and performance. There is good research evidence to show that well designed assessment systems lead to improved student performance."

\section{Conclusions}

Conclusions here are based on the visible results within the Moodle itself and on interviews with teachers and students. It can be seen that some teachers are beginning to put electronic materials that were prepared earlier into the learning environment to be freely available to students. Some of the younger teachers have even begun to prepare assignments, quizzes and other various activities for students.

Also, from the interviews with students, we see that they believe that by using the Moodle platform that they will improve their learning skills and their knowledge. They also say they are more motivated and interested and that they hope that over time more teachers will begin to use this platform. They have found that in a variety of electronic and multimedia lectures and activities, each student can find their own method of learning and their own learning style.

It is still early to say that this project has finished $100 \%$ successfully because the actual results of the overall project will have to wait at least a year, maybe more. During that time, there must be other activities which directly or indirectly encourage teachers to change the way they work and to gradually change their role from teacher to coach or mentor, and thus to increase their competencies in these directions.

Because it is a vocational school, in the future much work can be done on how to 
PROBLEMS

OF EDUCATION

IN THE $21^{\text {st }}$ CENTURY

Volume 39, 2012

14 incorporate video conferencing into the platform. Teachers would then be able to arrange online meetings between experts in certain areas and their students. It also could include portfolios for students and their activities and various workshops. It will bring improvement of group and team work between teachers and students. Preparations for these activities are already underway.

\section{References}

Dunn, R. \& Dunn, K. (1999). The complete guide to the learning style in-service system. Boston: Allyn \& Bacon.

Edgar Dale, (1969). Audio-Visual Methods in Teaching (3rd Edition). Holt, Rinehart and Winston

John Adams, (1923). The New Teaching. Limited 1925 London: Hodder and Stoughton

Johnson, L., Adams, S., and Haywood, K. (2011). The NMC Horizon Report: 2011 K-12 Edition. Austin, Texas: The New Media Consortium

OECD (2011), PISA 2009 Results: Students on Line: Digital Technologies and Performance (Volume VI). Paris, [Online]. Available: http://www.oecd.org/dataoecd/46/55/48270093.pdf [Accessed 26 Fevruary 2012]

Prashing, B. (2004). The power of diversity: new ways of learning and teaching through learning styles, Stafford: Network Educational Press.

UNESCO, (2005). Information and Communication Technologies in Schools: A Handbook for Teachers or How ICT Can Create New, Open Learning Environments (Ed. J. Anderson). UNESCO, Paris. [Online]. Available: http://unesdoc.unesco.org/images/0013/001390/139028e.pdf [Accessed 15 January 2012]

Vermunt, J. D. H. M. (1992). Leerstijlen en sturen van leerprocessen in het hoger onderwijs. (Learning styles and guidance of learning processes in higher education). Amsterdam/Lisse: Swets and Zeitlinger

William Rice, Susan Smith Nash, (2010). Moodle 1.9 Teaching Techniques: Creative ways to build powerful and effective online courses, Birmingham - Mumbai: Packt Publishing.

Yves Punie, Dieter Zinnbauer and Marcelino Cabrera, (2008). A Review of the Impact of ICT on Learning. Luxembourg, [Online]. Available: http://ftp.jrc.es/EURdoc/JRC47246.TN.pdf [Accessed 26 Fevruary 2012].

Advised by Mitko Kostov, Faculty of Technical Sciences, Bitola, FYR Macedonia

Received: January 24, 2012

Accepted: February 29, 2012

\begin{tabular}{|c|c|}
\hline Ilche Acevski & $\begin{array}{l}\text { Graduate Electrical Engineer (2002), Master's Degree in Information Technology (thesis } \\
\text { remaining), Teacher, Vocational School SOTU "Gjorgi Naumov", Crvena voda 25, Bitola, } \\
\text { FYR Macedonia. } \\
\text { E-mail: iacevski74@gmail.com } \\
\text { Website: http://e-uciliste.acevski.net }\end{array}$ \\
\hline Valentina Acevska & $\begin{array}{l}\text { Graduate Mathematician (1999), Master's Degree in Information Technology (thesis } \\
\text { remaining), Teacher, Vocational school SOU “Taki Daskalo”, Crvena Voda 25, Bitola, } \\
\text { FYR Macedonia. } \\
\text { E-mail: valle.mk@gmail.com } \\
\text { Website: http://e-uciliste.acevski.net }\end{array}$ \\
\hline $\begin{array}{l}\text { Linda Fahlberg- } \\
\text { Stojanovska }\end{array}$ & $\begin{array}{l}\text { Ph.D., U. "St. Clement of Ohrid", Faculty of Technical Sciences, Bitola, FYR Macedonia, } \\
\text { (Full) Professor of Mathematics and Information Sciences. } \\
\text { E-mail: Ifahlberg@gmail.com }\end{array}$ \\
\hline
\end{tabular}

